\title{
Parks' In The Blood: An Image of a Black Woman Who Is More Sinned against than Sinning
}

\author{
Ashraf A. Hadia \\ Faculty of Arts, Assiut University, Egypt \\ Faculty of Education and Arts, Northern Border University, KSA \\ Tel: 966-599-359-590_E-mail: ashrafabdell@yahoo.com
}

Received: April 13, 2012

Accepted: April 30, 2012

Published: June 1, 2012

doi:10.5539/ells.v2n2p105

URL: http://dx.doi.org/10.5539/ells.v2n2p105

\begin{abstract}
This paper seeks to reveal how Parks managed to present an image of a black woman who is brutally victimized by the social system through analyzing her play, In the Blood (1999. In that play, the social ills of hypocrisy, violence, discrimination, and sexual harassment are strongly emphasized. In a satirical style, the author could show how society blames and punishes those who are mainly created by its different own institutions and organizations at the same time. Although she does not give solutions, she calls for a reform of these agencies to let all people, whether poor or rich, receive the same level of societal care.
\end{abstract}

Keywords: Black woman, Hester La Negrita, Slut, Social institutions, Poverty, Hypocrisy

\section{Introduction}

As a Black person writing for theatre, what is theatre good for? What can theatre do for us? We can tell it like it is; tell it as it was; tell it as it could be. In my plays I do all 3; and the writing is rich because we are not an impoverished people, but a wealthy people fallen on hard times.

Suzan-Lori Parks

Suzan-Lori Parks is the first African-American woman playwright to receive the Pulitzer Prize for Drama in 2002. Although she is a young writer, she is one of America's most prolific and distinguished playwrights. She could produce a lot of impressive works such as plays, screenplays, books and essays. This paper seeks to reveal how Parks managed to present an image of a black woman who is brutally victimized by the social system through analyzing her play, In the Blood (1999) — one of two plays known collectively as The Red Letter Plays. In that play, it is obvious that the social ills of hypocrisy, violence, discrimination, and sexual harassment are strongly emphasized by the author. Although the protagonist of this piece of drama is black, readers should not interpret things with regard to racial concepts. They should, instead, consider it as a work of art that deals with a human being's case in general. For instance, Hester La Negrita, the protagonist, is oppressed by Reverend D. and the Welfare Lady, who are African Americans, as well as by the Doctor and Amiga Gringa, who are white. So the issue is not who is black and who is white, but it is who is responsible for what she suffers from. Parks herself resists the idea of being put within the frame of being an African-American writer concerned only with the Black culture. She says:

It's insulting, when people say my plays are about what it's about to be black-as if that's all we think about, as if our life is about that. My life is not about race. It's about being alive. [. . .] Why does everyone think that white artists make art and black artists make statements? (Solomon, 1990, p. 73)

And:

I really get a little ill when people use only my African-Americanness to talk about my plays. [. . .] They [the plays] go beyond subject matter, beyond the characters, beyond the plot, to a kind of world view made up of a cultural history. (Madison, 1991, p. 37)

Sometimes, African Americans themselves could be the source of oppression of their own community according to Parks' play.

\subsection{Suzan-Lori Parks}

Suzan-Lori Parks was born on 10 May 1963, in Fort Knox, Kentucky in a military family. She was traveling across 
the United States until the family was transferred to Germany. There, she spent a part of her childhood and attended German junior high school instead of the English speaking school for military children. She quickly learned to speak German. The experience, in addition to learning the fundamentals of language, showed Parks what it feels like to be neither white nor black, but simply a foreigner. As being a daughter of a colonel in the US Army, Parks, who was writing stories at the age of five, had a nomadic childhood as her father's career had required. This has provided her with a rich human experience to be used for her literary works. She eventually returned to the United States and graduated from The John Carroll School in 1981. Later, she attended, and graduated from Mount Holyoke College in 1985 in English and German literature.

As an undergraduate at Mt. Holyoke College, she studied with James Baldwin, the African-American novelist and playwright who was teaching a writing class there. He encouraged her to write not just short stories but plays because of her fondness for writing dialogue. While still in school, she wrote her first play, The Sinner's Place (1984). She won Obie Awards for her third play, Imperceptible Mutabilities in the Third Kingdom (1989), and for her eighth one, Venus (1996). In 1996, too, she wrote her first screenplay for the film, Girl 6. Her other plays include The Death of the Last Black Man in the Whole Entire World (1990), The America Play (1994), In The Blood and Fucking A (1999), known as The Red Letter Plays - which are both a retelling of Nathaniel Hawthorne's novel, The Scarlet Letter (1850). Her 2001 play, Topdog/Underdog - a play about family identity, fraternal interdependence, and the struggles of everyday African American life - won the Pulitzer Prize for Drama in 2002. From November 2002 to November 2003, Parks wrote a short play each day for a year. The result of this process is the 365 Days/365 Plays series.

Through her plays, Parks could reach a position of self-expression she doesn't reach in her real life; a great loud sound that speaks very well of her. Her works speak for those whose voices have been muted; the voices of the poor black women. She has taken those voices and placed them in the front for all to hear. Her individual voice speaks on behalf of the members of her community. She moves from the individual to the collective identity as it was done with Lorraine Hansberry's A Raisin in the Sun (1959) which portrays the reality of many African Americans living during the 1940s and 1950s - poverty, unemployment, and racism — by focusing on a specific family living in Southside Chicago.

In fact, Suzan-Lori Parks is really different from other playwrights where she invents her own rules of language and pauses. She writes in a nontraditional style where she uses dialectal spelling to show the low environment of those people on behalf of whom she speaks. For instance, "Hester uses language symbolizing her life beneath, below, and beyond the gaze of society" (Krasner, 2000, p. 565). She eliminates certain types of punctuation such as substituting the conventional punctuation with using intervals of silence which she refers to as a dramatic pause by repeating character names for emphasis as well as putting parentheses around things she thinks are unnecessary to the play's advancement. Also, she introduces distinguished stylistic features such as the doubling of characters, naming her characters with words that bear meaning of the traits of each character, and using a series of a soliloquy-like "confessions" that work as divisions of her work-a "shifting narrative" in which the author moves away from her central protagonist to offer an intimate look into the inner thoughts of other characters through monologues and songs. In addition, her lack of stage directions drives critics to believe that, "meaning is embedded in the sound of the words, and reading the plays aloud is crucial to penetrating their mysteries" (Peterson, 1997, p. 271).

\section{In The Blood}

In The Blood was premiered in 1999 in New York at the Joseph Papp Public Theatre and was nominated for the Pulitzer Prize. The influence of the Nathaniel Hawthorne's novel The Scarlet Letter-the American novel of guilt and adultery set in Puritan England - is clear as a background of that play where Hester La Negrita plays the role of the Black surrogate woman for Hester Prynne. The novel, whose central character, Hester Prynne, who was wearing a red $\boldsymbol{A}$ embroidered on her dress, has been the source for the main theme of the play, where society has no sympathy for those who are socially outcast:

Just as Hawthorne uses a white female Hester Prynne to critique the hypocrisy of $19^{\text {th }}$ century puritanical society, which was the mainstream at that time, Parks contrives a black Hester to satirize contemporary American mainstream culture in In The Blood. (Park, 2008, pp. 129-130)

By replacing the white character with a black one, the author has succeeded to criticize the American society. In a satirical style, she could show how society blames and punishes those who are mainly created by its different own institutions and organizations at the same time. Hester La Negrita, the heroine, works insistently to establish a new life for herself and for her homeless family. She is a woman who is at war with poverty, the welfare system and society. For the playwright, the scarlet letter is just an $\boldsymbol{A}$ that Hester keeps trying to write in the dirt hoping to get her "leg up" in her society till she tragically writes it with her beloved son's blood. Suzan-Lori Parks succeeds to present an image of a black woman whose fate has put her in such a community and situation where she moves from the 
specific to the collective. The character of Hester La Negrita presents the image of all the African-American women who suffer at the cruel hands of the social system under which they live, where they face financial and sexual oppressions. On the other hand, Parks works on assembling "characters and stories that revel in the fact that identities and places are highly mobile and integrated. She creates works that inhabit the margins [...]" (Elam, 2001, p. 233).

The play deals mainly with the story of Hester La Negrita who works hard to find a place for her and her stricken family in a society devoid of mercy for the poor. The world around her looks on raising five children to be an impossible achievement. The protagonist is a homeless single mother living under a bridge and struggling to support her five children while being exploited by everyone she meets. Each of her five children has a different father, that's why she must struggle to support her own family with little help from either her ex-lovers or from the social and governmental aid. The most prominent fathers are Reverend D. (who is the father of Hester's youngest child) and Chilli (who is the father of Hester's oldest child). Amiga Gringa, Hester's white friend, offers Hester advice on how to rid herself of children and to ease her motherhood burden. Amiga Gringa steals from Hester every chance she gets. A black woman named "Welfare" expects favors from Hester but does not offer much in return. The characters Reverend D. and the Doctor exploit Hester sexually fulfilling their animal desires in a very brutal way. Throughout the play, Hester experiences many severe stomach pains as a result of not eating regular meals. Even her children eat very little. They often question their mother about their fathers. None of the fathers pays child support nor helps Hester and her five children in any way. Some of the fathers curse Hester even while they continue having sexual relationships with her. They use their power to dominate her without having any kind of shame or mercy. The children — with names like Jabber (13-year-old boy), Bully (12-year-old girl), Trouble (10-year-old boy), Beauty (7-year-old girl) and Baby (2-year-old boy) - remind Hester of both her mistake and of the joy of having them as her "treasures". Towards the end of the play, her frustrations come to a dramatic climax when she becomes infuriated on hearing her son repeating the word "SLUT". She murders her oldest son, Jabber, with a police club, in a violent fit of disappointment. Verna A. Foster (2007) concludes that "the child's behavior is simply the last in a series of abuses inflicted on Hester throughout her life and over the course of the play" (p. 79).

In Parks' new vision, women, represented by Hester, are not working against the confinement of the Puritan society of Hawthorne but instead are facing tension and restriction as single black women within a modern society. They are neglected and maltreated by the same social institutions created to provide care and compassion to the poor. Here, Suzan-Lori Parks focuses on the point that illiteracy and unemployment have marginalized and impoverished large numbers of young black women which became the major cause behind forcing the heroine to resort to violent acts of destroying herself and her own family. Although the hypocritical society institutions are all responsible for what she is suffering from, she, herself, is to blame, in part, for her own catastrophe and her social exclusion. She is victimized not only by the five absent fathers but also by the social forces and her own best apparent friend, Amiga. She is manipulated by forces she cannot control. Nevertheless, she still has a strong will to survive as well as a hope to keep her life going on.

\subsection{Analysis}

As a matter of fact, this piece of drama manifests the talent of the author who presents a tragedy of a black woman living in the late twentieth century society. She took a classic novel and reworked it into a modern play. Her play's cast consists of six adult characters; five of them double as adults and children. The setting, now and here, reflects the poverty of the whole atmosphere of Hester's life

\subsubsection{Chorus}

The play begins with a prologue in which actors form a kind of chorus representing the society which excludes Hester. This chorus mocks her both at the beginning and at the end as being an illiterate woman who "CANT READ CANT WRITE'. In addition, they all refer to her as a 'SLUT,' a 'HUSSY' and a 'BURDEN TO SOCIETY':

(All clustered together)

SHE DONT GOT NO SKILLS

CEPT ONE

CANT READ CANT WRITE

SHE MARRIED? 
CAUSE OF

GIRLS LIKE THAT

SHE GOT FIVE OF THEM

FIVE BRATS

AND NOT ONE OF THEM GOT A DADDY

[She is]

SHEFTLESS

HOPELESS

BAD NEWS

BURDEN TO SOCIETY

HUSSY

SLUT

BAD NEWS IN HER BLOOD

PLAIN AS DAY. (Parks, 2003, pp. 1624-1625)

In this prologue, Parks takes us back to the style of Greek writers who make good use of the chorus which introduces actions and predicts what is going to happen in future as well as commenting on events. From the early beginning, the audience perceives that there is a seed of rage growing gradually inside the protagonist on noticing the word "slut" scribbled on the wall where she practices learning how to write and how to read - though the only letter she can make is just ' $A$ '. She is angry not because she knows the meaning of the word, but just because she likes her "place clean". This kind of anger, created by society, grows to be the main reason behind the final bloody action.

In the first scene, Hester and her son Jabber are seen entering and talking about the letters that have been written on the wall of their 'home' under the bridge. Hester, who is illiterate, cannot read the letters of the word 'SLUT'. The "letters" of the word are still "mysterious to her". Therefore, she asks her eldest son, Jabber to read it. But, in order to protect his mother's feelings, he pretends that he cannot read it:

HESTER: Read that word out to me, huh? I like it when you read to me.

JABBER: Don't wanna read it.

HESTER: Cant or wont?

JABBER: - Cant.

HESTER

JABBER

(He knows what the word says, but he wont say it.)

HESTER: We know who writ it up there. It was them bad boys writing on my home. And in my practice place. Do they write on they own homes? I don't think so. They come under the bridge and write things they don't write nowhere else. A mean ugly word, I'll bet. A word to hurt our feelings. And because we aint lucky we gotta live with it. 5 children I got. 5 treasures. 5 joys. But we aint got our leg up, just yet. So we gotta live with mean words and hurt feelings. (ibid., p. 1626)

It is this word - with which society has branded Hester as an immoral outcast — which later leads to the desperate and inevitable murder of Jabber. With this word too, Parks keeps her audience busy all the time looking at the wall on which the bad word is written. This stage technique used by the author makes the audience occupied with the question of what will happen as a result of that word. All the time, they watch it there as a background of actions. They think of and may imagine things that could be related or not to the meaning of that word. Nevertheless, its presence anticipates something not known to them yet. They may ask themselves: can that word hurt and lead to horrific actions? Or is it just a word leading to nothing? 
Although the chorus considers Hester's five fatherless children 'BASTARDS', she, as a mother, has deep love for them and looks on them to be her five "treasures" who give meaning to her existence. They are more precious than money. She prefers these "treasures" to herself:

(They slurp down their soup quickly. As soon as she fills their bowls, theyre empty again. The kids eat. HESTER doesnt)

JABBER: You aint hungry?

HESTER: I'll eat later.

JABBER: You always eating later.

HESTER: You did a good job with the wall, Jabber. Whatd that word say anyway?

JABBER: -Nothing.

(The soup pot is empty.)

HESTER

$J A B B E R / B U L L Y / T R O U B L E / B E A U T Y / B A B Y$

(Rest)

HESTER: Bedtime.

BULLY: Can we have a story?

(Rest)

HESTER: All right. (Parks, 2003, p. 1627)

This precious kind of love and care reminds us of the 'Black' mother figure who is always presented historically in literature as someone who, at all costs, nurtures, protects, and cares for her children. The mother is always devoted and self-sacrificing. But even this kind of unconditional care and love, provided by Hester to her five fatherless children, does not make her content as long as these children are an outcome of illegal relationships. Foster (2007) states that this " "motherlove' is soured and corrupted by societal evil" leading to a horrible act of bloodshed by the end (p. 83). She could not become a mother without errors. Her status as a social outcast partly results from the fact that, according to the chorus, 'SHE OUGHTA BE MARRIED', but she is not. It is her fault not to marry and live a normal life. She could not differentiate between love and love making.

\subsubsection{Amiga Gringa}

In an impressive scene, the readers and the audience feel pity towards the heroine who is psychologically, economically and socially suffering from all the social forces around her. Yet, she still keeps some kind of powerful spirit inside enabling her to be capable of working hard on satisfying all her children's needs. In his comment on Hester's character, Deborah Gies (2004) suggests that "Hester has a gifted imagination" seen especially when "she helps the children to enjoy the meager soup that she feeds them for dinner by telling them that it has everything they love in it"(p. 83). After feeding her children, she puts them to bed and starts to tell them tales so as to make them sleep. Amiga comes in to mock her as being an old woman who is always committed to her kids neglecting herself.

Amiga Gringa and Hester are two "friends" who try all the time to use each other to better their own conditions. Amiga is a poor white woman who claims to share in Hester's oppression but actually participates in it. Parks satirically presents Amiga as a victim and as a convict at the same time. Amiga claims that she can help Hester but in fact she can not help herself and that is why she steals food and money from her friend as well as selling her own babies for profit. In her confession, she bares herself before the audience:

AMIGA GRINGA:

I had me some delicious schemes

To get her out of that hole she calls home.

Im doing well for myself

Do you have any idea how much cash I'll get for the fruit of my white womb?!

Grow it.

Birth it. 
Sell it.

And why shouldn't I?

(Rest)

Ah, what do you expect in a society based on Capitalizm. (Parks, 2003, p. 1639)

Amiga, who makes money by selling "the fruit of [her] white womb" without feeling guilty, tries to exploit Hester by convincing her to follow the same way she does - to use her body to get money. Although she is so poor, she refuses to work and criticizes sewing as a good profession, implying that it is beneath her. After refusing Hester's offer to find her sewing work, she explains, "Thats not for me. If I work Hester, I would want to be paid a living wage. You have agreed to work for less than a living wage. May as well be a slave. Or an animal." She calls that kind of work a "Chump work" that leads to nothing (ibid., p. 1638). She takes the fabric given to Hester by the Welfare Lady to sell it in the open market in order to offer help, but she is actually trying to steal it as she did before with the money she got from selling Hester's watch without returning all the money back. She is a real cheater who exploits the poor Hester to the end:

HESTER: Where the rest?

AMIGA GRINGA: That's it.

HESTER: 5 bucks?

AMIGA GRINGA: It wasn't a good day. Some days are good and some days are bad. I kept a buck for myself.

HESTER: You stole from me.

AMIGA GRINGA: Don't be silly. We're friends Hester.

HESTER : I shoulda sold it myself.

AMIGA GRINA: But you had the baby to watch.

HESTER: And no ones gonna give money to me with me carrying Baby around. Still I coulda got more than 5. (ibid., p. 1629)

In spite of all what has happened previously between Hester and Amiga, they are still friends because they need each other in order to survive. Hester needs Amiga in order to sustain her life; no matter how mean she is, while Amiga uses Hester anyway she can so as to improve her own life. She not only cheats but also drives her to give up the job of sewing. She is interested to keep Hester needy all the time as long as she profits from her existence.

Hester is naïve enough to believe that her community and the world around will help her even though she is stigmatized with sin. She says that, "the worldll take care of the women and children," and "All I need is a leg up. I get my leg up I'll be ok." But the fact is something else; she is mistaken to believe that in such a capitalistic world of contemporary America. Park (2008) assures that by saying that the "Parks's dramatic strategy of rewriting Hawthorne's Hester and her suffering can be accepted as a subversive critique against contemporary American society" (p. 130).

\subsubsection{The Welfare Lady}

In addition to Amiga, the Welfare Lady, who represents the Welfare system in society, blames Hester for being poor, homeless, and with five children forgetting that Hester is a part of that society which should take care of such a woman as being a part of its structure. Although the Welfare Lady gives Hester a sewing job, she does not teach her how to sew. This kind of satire shows that society is doing that just as a matter of show, and not for the sake of real and honest help. Here, poverty is often blamed and not those who are behind that poverty:

WELFARE: The welfare of the world weighs on these shoulders, Hester.

(Rest)

We at Welfare are at the end of our rope with you. We put you in a job and you quit. We put you in a shelter and you walk. We put you in a school and you drop out. Yr children are also truant. Word is they steal. Stealing is a gateway crime, Hester. Perhaps your young daughter is pregnant. Who knows. We build bridges you burn them. We sew safety nets, rub harder, good strong safety nets and you slip through the weave.

HESTER: We was getting by all right, then I dunno, I been tired lately. Like something in me broke. (Parks, 2003, p. 1635)

Hester confesses that she was about to feel good, then something broke in her. When she went to the shelter, she has 
been harassed by all people there. She says that she has tried to "make ends meet" but instead "ends got further apart." She has found that the social helping agencies are interfering in her life through their representatives who systematically exploit her in a bad way. As a result of that, she loses trust in such a deceptive system which claims to have concern for her welfare but in fact it does not. The Welfare Lady and her husband have used her all the time selfishly for their self-gratification. The audience would be shocked on hearing the Welfare Lady saying that what she does is her job; she cares for Hester only because it is her job to care, she is paid to stretch out her hands, and she believes that nothing comes out of nothing. Instead of encouraging Hester and her children to be good members of society, she blames them for the poor life they lead. Furthermore, she goes to the extreme by accusing Hester's daughter of making adultery a generational sin. Of course, this kind of accusation creates a kind of a frustrated and a desperate spirit inside Hester's character. It becomes very clear that the Welfare Lady deals very cruelly with Hester who does not have any power to resist the aggression of the woman from whom she has expected to receive help:

HESTER: I want my leg up is all.

WELFARE: You wont get something for nothing.

HESTER: I been good.

WELFARE: 5 bastards is not good. 5 bastards is bad.

HESTER: Don't make me hurt you!

(HESTER raises her club to strike WELFARE)

WELFARE: You hurt me and, kids or no kids, I'll have you locked up. We'll take yr kids away and yll never see them again.

HESTER: My lifes my own fault. I know that. But the world dont help, Maam.

WELFARE: The world is not here to help us, Hester. The world is simply here. We must help ourselves. (ibid., $p$. 1636)

The tragic flaw of Hester is that she does not know the difference between love and love making. Yet, as a brave person, she admits that the fault is hers and she is herself responsible for what happens. The audience becomes very sympathetic on watching her bearing all these sufferings and nevertheless she still has some kind of will and courage to take responsibility. In spite of all that, she continues to be that mother who protects and defends her existence with her five fatherless kids. She is devoted and caring for her kids. In relation to this, Foster (2007) points out that Hester attempts to conform to the conventional model of the "good mother", but the strain of doing so without any support from society contributes to her fatal actions against her own beloved child (p. 78). On the other side, as a woman, she does not stick to the morals of the proper womanhood as long as she is not a married woman. In her confession, the Welfare Lady considers such a type of woman inferior:

I should emphasize that she is a low-class person. What I mean by that is that we have absolutely nothing in common. As her caseworker I realize that maintenance of the system depends on a well-drawn boundary line and all parties respecting that boundary. And I am, after all, I am a married woman. (Parks, 2003, p. 1637)

Hester is not only victimized by her own black people — represented by the Welfare Lady—but also condemned by society at large - represented by the Welfare social system. Finally, it is Hester who bears the burden of each sin; by bearing children that represent that sin. Yet, Schafer (2008) defends and considers her refusal to name or blame those who would oppress her a brave act that may "allow us to perceive her as a tragic hero with a tragic flaw who brings about her own downfall" (p. 192).

\subsubsection{The Doctor}

Furthermore, the Doctor, who represents the health agency, treats her in an inhuman manner when he examines her in the street as if she were an animal. Parks describes the Doctor as a person who is not organized and looks like a hawker who sells his goods in streets. He "carries all of his office paraphernalia on his back." He starts to check her in public as she has stomach pain due to the lack of regular meals:

DOCTOR: Howre yr meals?

HESTER: The kids come first.

DOCTOR: Course they do. Howre yr bowels. Regular?

HESTER: I dunno.

DOCTOR: In a minute. Gimmie the Spread \& Squat right quick. Lets have a look under the hood. 
Yr kids are 5 strikes against you. (Parks, 2003, p. 1632)

The Doctor is like a mechanic who is checking an impaired vehicle. He tells her that the only way to control her birth rate is to have her spayed. He thinks that spaying is the best solution to Hester's problems. He wants to remove her woman parts in order not to beget more children. By doing that, he subverts her womanhood, motherhood, and humanism. He seeks to destroy her capacity to bring any other new life in order to keep his own position high. This selfishness appears clearly when he tells her: "Every blemish on your record is a blemish on mine. . . You and yr children live as you please and Im the one The Higher Ups hold responsible" (ibid., p. 1631). Although the Doctor seems to care for Hester's life on some level within the Welfare system, he, as the Welfare Lady has done before, takes advantage of her. He is ultimately self-serving. He manipulates controls and uses Hester's body to satisfy his own low animal desires. Yet, he blames and counts her to be the one who is in charge. In his confession, he declares:

I was

lonesome and

she gave herself to me in a way that I had never experienced

even with women Ive paid

she was, like she was giving me something that was not hers to give me but something that was mine

that I'd lent her

and she was returning it to me. (ibid., $p$. 1633)

According to Elam (2001), both the Doctor and the Welfare Lady justify their organized exploitation of Hester through finding that the sexual desire enables them to cross boundaries of class and good manners in order to attain some kind of self pleasure. But the case is different with Hester who "finds no sense of self, no freedom in these acts. Sex does not liberate her from but only imprisons her more in the system" (p. 123).

\subsubsection{Reverend D.}

Mistakenly, Hester has thought that she can get love through being used by those who are in power. The priest, Reverend D., the one who represents church, is accustomed to treat her as being just a source of physical satisfaction regardless of giving her any kind of emotional or financial support. As a result of their illegal relationship, she gets her latest child "Baby." Cowardly, he acts as if he has nothing to do to take responsibility towards the child. Parks, in a very famous confrontation between Hester and Reverend D., presents a poignant satire directed to the double-faced church. When Hester asks Reverend D. how to confront a father who does not pay any kind of support for his child, the following dialog takes place as he looks at Baby's picture:

HESTER: This child here don't know his daddy.

REVEREND D.: The ultimate disaster of modern times. Sweet child. Yours?

HESTER: Yes.

REVEREND D.: Do you know the farther?

HESTER: Yes.

REVEREND D.: You must go to him and say, "Mister, here is your child!"

HESTER: Mister here is your child!

REVEREND D.: "You are wrong to deny what God has made!"

HESTER: You are wrong to deny what God has made!

REVEREND D.: "He has nothing but love for you and reaches out his hands every day crying wheres daddy?"

HESTER: Wheres daddy?

REVEREND D.: "Wont you answer those cries?"

HESTER: Wont you answer those cries?

REVEREND D.: If he don't respond to that then hes a good-for nothing deadbeat, and you report him to the authorities.... I have a motivational cassette which speaks to that very subject. I'll give it to you free of charge. (Parks, 2003, p. 1634)

In this impressive dramatic scene, the hypocrisy of the religious institution agent is satirically presented to the 
audience who knows who the father of Baby is. In this converstion, Hester repeats all of the priest's words back to him as he tells her how to confront the father of her child. Reverend D. does not have any kind of mercy or courage to admit that he is the real father of that child. On the other side, Hester catches the audience's sympathy when she says that the "Doctor says I got a fever. We aint doing so good. ... They breaking my back is all. 5 kids.... Theres so many things we need. Food. New shoes. A regular dinner with meat and salad and bread" (ibid., p. 1635). In spite of all these sufferings, she bears all the atrocities with dignity and tells Reverend D. that she is still good and does not complain.

Although Reverend D. makes a powerful speech about how to help those who are less fortunate, he never takes any positive action that could change Hester's life to the better (Bell, 2006). Ironically, he uses a hollow preaching speech when saying, "Life on earth is full of confusion. Life on earth is full of misunderstandings, reprimandings, and we focus on the trouble, friends, when it is the solution to those troubles we oughta be looking at"(Parks, 2003, p. 1628). But the audience knows that he is a great hypocrite who says something and does another. When Hester asks him to help her with money for his baby, he refuses even to acknowledge neither her nor her youngest child as his own baby. Although he preaches about charity and social uplift of the poor people in society, he does nothing for Hester as mentioned before. He not only calls her a "slut", but also humiliates and threatens to "crush" her "underfoot" as well:

REVEREND D.: I'll have my lawyer deliver the money. Its better if you dont come back. Its too dangerous. My following are an angry bunch. They dont like the likes of you.

HESTER: But you do. You like me.

REVEREND D.: Youd better go.

HESTER: Why you don't like me? Why you don't like me no more?

(He tries to go back inside. HESTER grabs ahold of him)

HESTER: Dont go.

REVEREND D.: Take yr hands off me.

HESTER: Why you dont like me?

(They struggle.... He brutally twists her hand. She recoils in pain and falls to the ground.)

REVEREND D.: Slut.

(Rest)

Dont ever come back here again! Ever! Yll never get nothing from me! Common Slut. Tell on me! Go on! Tell the world! I'll crush you underfoot. (ibid., pp. 1646-47)

In the above dialog, Parks presents Reverend D. to the audience as a priest without any religious ethics; he strongly condemns something he himself has done. Hester reaches the point of being helpless before all the powerful social forces; all people are like the preying vultures surrounding her without giving any chance to let her get her "leg up". On the other hand, Chilli, who fathers Hester's oldest son, comes back after changing his name not to be found by the Welfare. He did so to evade any responsibility towards Hester and his own son, Jabber. He tells her that he has been searching for her in order to get married, but in fact he is a big hypocrite.

\subsubsection{Chilli}

In a remarkable scene reflecting how much naïve and simple Hester is, she wears the wedding dress offered by Chilli over her old clothes and gets out new special shoes to wear as if she has been preparing all her life for that moment. But, in a tragic moment, all her dreams to be a good woman collapse once Chilli discovers that she is not the woman he imagines to be. Ironically, he rejects her for the same qualities that he once admired in her-passion and love making. Indeed, Chilli imagines Hester as a Virgin Mary figure and her son like Jesus. Chilli takes back his proposal of marriage as soon as he meets all her other children. He explains:

CHILLI: Im—. I'm thinking this through. I'm thinking this all the way through. And I think—I think-.

(Rest)

(Rest)

I carried around this picture of you. Sad and lonely with our child on yr hip. Struggling to make do. Struggling against all odds. And triumphant. Triumphant against everything. Like—hell, like Jesus and Mary. And if they could do it so could my Hester. My dear Hester. Or so I thought.

(Rest) 
But I dont think so.

(CHILLI takes her ring and her veil. He takes her dress. He packs up his basket.) (ibid., p. 1645)

\section{Hester's Fate}

Bit by bit, Hester finds herself ostracized by all in society. Everything is dim in her eyes, and the world is eating her up. Now, the circle comes full and the play ends up as it has begun; Jabber reminds his mother of the word previously written on the wall by the bad boys. He says that he has lied to her when he pretended that he does not know how to read that word at that time. But in fact he knows how to read it and knows what it means as well. Whether he says the word or he calls her the word, Jabber drives his mother to become very infuriated and outraged:

JABBER: Them bad boys had writing. On our house. Remember the writing they had on our house and you told me to read it and I didn't wanna I said I couldnt but that wasnt really true I could I can read but I didnt wanna.

HESTER: Hush up now.

JABBER: I was reading it but I was only reading it in my head I wasnt reading it with my mouth I was reading it with my mouth but not with my tongue I was reading it only with my lips and I could hear the word outloud but only outloud in my head.

HESTER: Shhhh.

JABBER: I didnt wanna say the word outloud in your head.

HESTER

JABBER: I didnt wanna say you the word. You wanna know why I didnt

wanna say you the word? You wanna know why? Mommie?

HESTER

(Rest)

HESTER: What.

JABBER: It was a bad word.

JABBER: Wanna know what it said? Wanna know what the word said?

HESTER: What.

$J A B B E R$

HESTER: What?

JABBER: "Slut."

HESTER: I said I dont wanna hear that word. How slow are you? Slomo.

JABBER: Slut.

HESTER: You need to close yr mouth. Jabber.

JABBER: I know what it means. Slut.

HESTER: (Shut up.)

JABBER: Slut.

HESTER: (I said shut up, now.)

JABBER: I know what it means.

HESTER: (And I said shut up! Shut up.)

JABBER: Slut. Sorry.

(The word just popped out, a childs joke. He covers his mouth, sheepishly. They look at each other. . . HESTER quickly raises her club and hits him once. Brutally. He cries out and falls down dead. [. . .] HESTER beats Jabbers body again and again and again. [. . .] HESTER looks up from her deed to see BEAUTY who runs off. HESTER stands there alone-wet with her sons blood. Grief-stricken, she cradles his body. Her hands wet with blood, she writes an "A" on the ground.)

HESTER: Looks good, Jabber, dont it? Dont it, huh? (ibid., p. 1647) 
Hester has nothing to do against her Fate represented symbolically by the hand which blocks out the sun "with its 5 fingers coming down on" her. In a moment of unbearable stress and frustration, she beats her own beloved son to death. That fatal "violence against the child does seem to be motivated in part by her desire to destroy the "weak and despised' part of herself'(Foste, 2007, p. 82). Finally, she comes to recognize that she has had 5 mistakes not 5 treasures as she believed before. The Chorus appears again, in the epilogue, to reaffirm what they foretold before that "IT WONT END WELL FOR HER." The end is terrifying but it is a step in the process of catharsis; catharsis of all those who watch and read that tragedy. In an interview, Parks claims that "the play creates a wound that is actually the first stage in the healing process"( $q t d$. in Schafer, 2008, p. 194).

Elam (2001) suggests that Hester La Negrita "is a victim, but also tragically complicit in her own oppression. Her tale offers a poignant, contradictory conjunction of suffering and survival, institutional neglect, and individual abuse" (p. 117). She ends the play unable to express herself and unable to bear more children and create the "whole army" of "Bad Bastards" that may have protected her from the aggressive world (Parks, 2003, p. 1648). All are shamefully involved in her downfall: the community, Amiga Gringa, the Welfare Lady, the Doctor, Reverend D. Chilli, and of course, herself.

\section{Conclusion}

Through Hester La Negrita and her world, Suzan-Lori Parks could discuss a number of very important themes relevant to our culture such as: poverty, ignorance, violence, lack of education, hypocrisy of social institutions, social injustice, sexual harassment, and the importance of word in our lives. Every time the protagonist strives to "get a leg up," but to the contrary, she is over and over again pulled back down. The accumulated pressures of indifference and disregard lead to a violent tragic conclusion. Parks does not offer any solution to the problems raised in the play. Instead, she puts it clear before the audience that a re-evaluation and a re-consideration of the materialistic and social values are important to fill the gap between the poor and the rich, between those who suffer and those who are the source of that suffering. As a result of all that, readers would expect that a good world could be created out of that negative one presented by the author. According to Helman (2006), Parks "does not demonstrate a loss of hope in humanity, but mistrust of a powerful and corrupt system" (p. 169). She does unmask the powerful social institutions as being the enemy of the individual. What she calls for is to make a reform of these agencies to let all people, whether poor or rich, receive the same level of societal care. We all should look for the real Hester every where and try to stretch out our hands with help.

\section{References}

Bell, L. (2006). Suzan-Lori Parks' In the Blood: Book About African American Woman Living In Poverty. Retrieved Sep. 25 2006, from http://www.voices.yahoo.com/suzan-lori-parks-blood-book-african-american-81069.html

Elam, H. J., \& Krasner, D. (Eds.). (2001). African-American Performance and Theater History: A Critical Reader. New York: Oxford University Press.

Foster, V. A. (2007). Nurturing and Murderous Mothers in Suzan-Lori Parks's In The Blood and Fucking A. American Drama, 16(1), 75-89.

Gies, D. (2004). Hawthorne's Hester as a Red-Lettered Black Woman?: Suzan-Lori Parks's In The Blood and Fucking A. Journal of American Drama and Theatre, 16(2), 77-87.

Helman. E. V. A. (2006). A Society Unmasked: Globalization And The Drama of Suzan-Lori Parks. Unpublished Diss., University of Oregon.

Krasner, D. (2000). In The Blood. Theatre Journal, 52(4), 565-67.

Madison, C. (1991, Oct.). Writing Home. Interview. American Theatre, 36-38.

Park, Y. N. (2008). Urban Hester as a 'Vagabond' and the Quest of Subjectivity in Suzan-Lori Parks's In the Blood. Journal of American Studies, 40(1), 129-147.

Parks, S.-L. (2003). In The Blood. In C. H. Klaus, M. Gilbert, \& B. S. Field (Eds.), Stages of Drama: Classical to Contemporary Theater ( $5^{\text {th }}$ ed.). pp. 1621-1648. New York: Bedford.

Peterson, J. T., \& Bennett, S. (1997). Women Playwrights of Diversity: A Bio-Bibliographical Sourcebook. Westport CT: Greenwood Press CT.

Schafer, C. (2008). Staging a New Literary History: Suzan-Lori Parks's Venus, In the Blood, and Fucking A. Comparative Drama, 42(2), 181-203.

Solomon, A. (1990). "Signifying on the Signifyin": The Plays of Suzan-Lori Parks. Theater, 21(3), 73-80. http://dx.doi.org/10.1215/01610775-21-3-73 